\title{
„Lamentował Dawid żałobną pieśnią nad Saulem i Jonatanem, jego synem" - egzegeza 2 Sm 1,17-27 jako biblijnego przykładu trenu
}

Przytoczone w tytule artykułu słowa, brzmiące po polsku dość niecodziennie, otwierają tren po śmierci Saula, króla Izraela, i Jonatana, syna monarszego. Wydają się też trafnie oddawać podjęte $\mathrm{w}$ niniejszym szkicu zagadnienie. Wprowadzają bowiem, po pierwsze, $\mathrm{w}$ jedną z najpiękniejszych pieśni żałobnych, jakie notuje Biblia, po drugie - w wymowny sposób prezentują środki literackie, które autor tego starotestamentowego utworu wykorzystał dla ukazania całości zamysłu kompozycyjnego i treściowego.

$\mathrm{Na}$ początku tych rozważań koniecznie należy zauważyć specyfikę tekstu, którego bohaterami są polegli na polu chwały wojownicy. Odróżnia to omawiany utwór od podobnej w wymowie, lecz całkowicie odrębnej w treści Księgi Lamentacji, w której dominuje nieutulony żal judejskiego patrioty i oddanego Bogu wyznawcy po zniszczeniu przez obce wojska Jerozolimy - jego ukochanego miasta, a zarazem stolicy upadającego królestwa. Tekst ten stanowi przedłużenie i rozwinięcie tematyki Psalmu 137, wyrażającego żal za utraconym świętym miastem. Oprócz niego treny w Księdze Psalmów reprezentuje wiele tekstów, wśród których na wyróżnienie zasługują między innymi psalmy: 44, 60, 74, 79, 80 oraz $88^{\text {ㄷ }}$. Lamentacje jako takie nie są oczywiście dziełem autorów biblijnych. Zaczerpnęli oni zarówno pomysł, jak i sposób przekazu ze starożytnej literatury bliskowschodniej, zawierającej znane przykłady lamentacji, zwłaszcza nad zniszczonymi miastami: Ur, Nippur, Uruk oraz całym regionem Sumeru ${ }^{2}$.

I Zob. szczegółowe wprowadzenie w ten gatunek psalmów - S. Mowinckel, The Psalms In Israel's Worship, Grand Rapids-Cambridge 2004, s. 191-223.

${ }^{2}$ Zob. D. Garrett, P.R. House, SongofSongs/Lamentations, Nashville 2004, s. $310-314$. 
Elegia o zmarłych nie występuje $\mathrm{w}$ tekście biblijnym zbyt często. Ze znanych zauważyć można jedynie Dawidową elegię o śmierci Abnera - wodza wojsk Saula, podstępnie zamordowanego przez Joaba - dowódcę wojsk Dawida, zazdrosnego o swe wpływy w armii i na dworze królewskiego następcy tronu $(2 \mathrm{Sm}$ $3,33)^{3}$.

Przechodząc do omówienia niektórych przynajmniej aspektów elegii na śmierć króla i jego syna, trzeba przypatrzeć się wpierw czasom, do których się odnosi i w których jest wyraźnie zakorzeniona. Drugim etapem będzie prezentacja jej całościowej kompozycji, co pozwoli w końcu na ukazanie zależności między treścią a jej układem.

\section{Tragiczny los bohaterów}

Wydarzenie, do którego nawiązuje omawiany tekst biblijny, nie zostaje podane bezpośrednio przed nim. Znajduje się ono w Pierwszej Księdze Samuela (1 Sm 31,1-13) opisującej klęskę wojsk Saula w bitwie z Filistynami. Relacja ta niezwykle krótko, jakby beznamiętnie przedstawia śmierć najważniejszych postaci ówczesnej historii Izraela. Oto w wersecie 1 autor biblijny relacjonuje, że żołnierze izraelscy uciekli przed Filistynami lub padli na wzgórzach Gilboa. Nie oznaczało to bynajmniej jeszcze końca walki, której kolejnym etapem było ich natarcie na przyboczną gwardię króla izraelskiego. Skutkiem tych wydarzeń była śmierć wszystkich synów królewskich biorących udział w bitwie: Jonatana, Aminadaba i Malkiszuy (w. 2). Szczytowym etapem klęski oddziałów izraelskich była batalia tocząca się wokół samego króla, który został wytropiony i zraniony przez łuczników wroga (w. 3). W tej sytuacji, nie mając już znikąd pomocy, ranny Saul zażądał od swego giermka, by go dobił dla uniknięcia skazy na honorze, jaką pozostawia zabicie przez obcych. Ten jednak odmówił, by nie targnąć się na pomazańca Bożego i nie stać się winnym krwi tego, którego Bóg namaścił na króla swego ludu (w. 4ab $)^{4}$. Wtedy Saul sam rzucił się na swój miecz (w. 4c), giermek zaś uczynił to samo, umierając wiernie przy boku władcy i wodza (w. 5). Po tym opisie hagiograf podsumowuje bitwę, w której polegli król, jego trzej synowie i wielu innych uczestników starcia (w. 6). Skutkiem śmierci bohaterów była nie tyl-

3 Zob. J.S. Synowiec, Gatunki literackie w Starym Testamencie, Kraków 2003, s. 105.

${ }_{4}^{4}$ Nieobrzezani jako ludzie godni pogardy, por. także: $\mathrm{Sdz} 14,3 ; 15,18 ; 1 \mathrm{Sm}$ 14,6; $1 \mathrm{Krn} 10,4$; Ez 32,21. 
ko klęska, lecz także konieczność opuszczenia przez Izraelitów całych połaci zamieszkiwanych przez nich terenów i zajęcie ich przez Filistynów (w. 7).

Druga część opowiadania biblijnego akcentuje przede wszystkim niegodziwe zachowanie zwycięzców, manifestujących całkowity brak szacunku wobec pokonanych. Obdzieranie poległych na polu walki jest postępkiem niegodnym i wyrazem nieposzanowania dla zmarłych (w. 8a) , wśród których odnaleziono i rozpoznano króla i jego synów (w. 8b). Zostali oni pozbawieni zbroi, królowi zaś odcięto głowę ${ }^{6}$, po czym rozesłano po ziemi filistyńskiej wiadomość o zwycięstwie, wzbudzając tym radość (w. 9). Wyrazem wdzięczności zwycięzców dla ich bóstw opiekuńczych było złożenie zbroi w świątyni bogini. Zwłoki króla i jego synów natomiast powieszono na murze jednej $\mathrm{z}$ twierdz filistyńskich (w. 10) - było to okazanie krańcowej pogardy wobec pokonanych $\mathrm{z}$ manifestacją prymitywnych zachowań cechujących ludzi pozbawionych szacunku dla ofiar batalii. $\mathrm{Na}$ wspaniały gest odwagi i szacunku zdobyli się za to mieszkańcy izraelskiej osady Jabesz, którzy pod osłoną nocy zdjęli ciało monarchy i pochowali je w grobowcu, oddając się praktykom pokutnym (w. 11-13). Tu następuje koniec Pierwszej Księgi Samuela, lecz autor - prawdopodobnie już inny - kontynuuje, przechodząc do Dawida, zwycięskiego przeciwnika Saula w rywalizacji o tron Izraela. Ten z kolei po wygranej bitwie z Amalekitami (1 Sm 30,1-31) zatrzymał się w jednej z miejscowości, czekając najwidoczniej na rozwój wypadków po stronie króla i jego oddziałów (2 Sm 1,1).

W tym momencie następuje druga część sceny będącej głównym tematem utworu 7 . Autor relacjonuje przybycie do obozu Dawida jednego z ocalałych w bitwie na wzgórzach Gilboa wojowników Saula, którego widok mówił sam za siebie: zwiastował klęskę (w. 2). Po przedstawieniu się następcy tronu (w. 3) przy-

5 Taką ocenę wystawia np. Hi 22,6; 2 Sm 23,10; 2 Krn 25,13 ukazują jednak odzieranie z cenniejszych przedmiotów, ubrań jako zwykły etap postępowania zwycięzców wobec pokonanych, jako zbieranie łupów.

${ }_{6}$ Musi zadziwiać akceptacja tego samego zwyczaju ze strony Izraelitów, co pokazuje akt dobicia Goliata przez Dawida w 1 Sm 17,51. Niektórzy egzegeci widzą w tym geście Filistynów swoistą teologię zemsty za odcięcie głowy Goliata zob. R.W. Klein, 1 Samuel, Waco 1983, s. 289.

7 Komentatorzy są zgodni w obserwacji, że oba opowiadania (1 Sm 31,1 $2 \mathrm{Sm} 1,1$ oraz $2 \mathrm{Sm} 1,2-10$ ) są niespójne redakcyjnie, na co wpływ miała tzw. redakcja salomonowa $\mathrm{w}$ pierwszej z perykop, kanonizująca sakralność urzędu królewskiego w strachu giermka $(1 \mathrm{Sm} 31,4 \mathrm{~b})$ oraz uszanowanie mieszkańców Jabesz dla osoby zmarłego króla (w. 11-13) - zob. J. Vermeylen, La Maison de Saül et la Maison de David. Un récit de propagande théologico-politique de $1 S 11$ à 2S 7, w: Figures de David à travers la Bible, Paris 1999, s. 48-49. 
bysz zdał relację z przebiegu bitwy, wymieniając wśród poległych także monarchę i Jonatana (w. 4). Zainteresowanie Dawida skupiło się na Saulu i Jonatanie, jednym z synów królewskich, o których żołnierz opowiedział ze szczegółami, wspominając zwłaszcza scenę dobicia Saula na jego żądanie (w. 5-9). Wojownik stwierdził, że zadośćuczynił prośbie władcy w przekonaniu, że jego życie dobiega już końca. Przybysz miał też przy sobie królewski diadem, zabrany, by przynieść go w dobrej wierze Dawidowi, nowemu panu (w. 10) $)^{8}$. Autor wspomina, że wojownik ów był osadnikiem amalekickim, czyli jednym z tych, z którymi Dawid prowadził zwycięskie potyczki (w. 8b). W zestawieniu z faktem, że wcześniej giermek królewski nie wykonał rozkazu swego zwierzchnika i nie dobił go, obecne wspomnienie pochodzenia wojownika jest ważne: izraelskiego władcę, członka narodu wybranego, zabił nieobrzezany, obcy i pogański żołnierz, stając się przez to winnym zbrodni zabójstwa i usprawiedliwiając tym samym wypadki, które sromotnie zakończą jego własne życie ${ }^{9}$.

Reakcją króla było zwyczajowe rozdarcie szat na znak żałoby, czemu towarzyszyło podobne zachowanie całej świty (w. 11) ro $^{\text {ro }}$. Nastąpnie szczere opłakiwano śmierć Jonatana oraz dotkliwą klęskę narodu wybranego (w. 12). Autor dołącza do tego jeszcze znamienne wydarzenie pomszczenia śmierci Saula przez Dawida na nieszczęsnym żołnierzu, który tamtego dobił. Uzasadnieniem czynu następcy tronu było głośne wyrażenie dezaprobaty wobec zachowania tego, który śmiał podnieść rękę na pomazańca pańskiego, przy czym Dawid odżegnał się od winy za swą zemstę, zrzucając odpowiedzialność na żołnierza - ten zaś własną mową poświadczył, że pozbawił życia władcę Izraela (w. 13-16).

${ }^{8}$ Autor biblijny zadbał o ważny szczegół: Dawid, już namaszczony przez Samuela w imieniu Boga (1 Sm 16), lecz odrzucający królewski diadem i pierścień Saula, nie chce przejmować władzy w narodzie wybranym ani w sposób bezpośredni, czyli bez uznania go przez cały naród, ani tym bardziej z rąk poganina - zob. J. Cazeaux, Saül, David, Salomon: la Royauté et le destin d'Israël, Paris, 2003, s. 157-158.

9 W relacji Amalekity można zauważyć przekłamania sytuacji, zwłaszcza w stwierdzeniu ucieczki z najbardziej zaciętej fazy bitwy i po dokonaniu morderstwa na królu. Autor zrzuca całą winę za decyzję Dawida o wyroku śmierci na winowajcę - zob. S.L. McKenzie, King David. A Biography, Oxford 2000, s. $104-105$.

ro Zachowanie to należy odczytywać jako typowe w okolicznościach zaskoczenia straszliwą w konsekwencji dla całego narodu wieścią o gwałtownej i bezlitosnej śmierci - zob. J. Goldingay, Israel's Faith. Old Testament Theology II, Downers Grove 2006, s. 309. 


\section{Ogólne spojrzenie na gatunek literacki}

W wersecie 17 autor wprowadza ściśle tematykę elegii, pisząc, że „lamentował Dawid żałobną pieśnią nad Saulem i Jonatanem, jego synem", polecając dodatkowo, by pieśń tę zanotować w nieznanej już dziś i zaginionej „Księdze Sprawiedliwego” (w. 18). Pierwszy z tych wersetów jest szczególnie wartościowy dla omawianego zagadnienia, ponieważ zawiera to, co literaturoznawcy mianują elegią lub trenem. Chodzi o hebrajski czasownik qîn, oznaczający „śpiewać żałobnie, zawodzić, lamentować” oraz powstały od niego rzeczownik qîna - „lamentacja, tren”. Interesująca część tego zdania w oryginale brzmi: „wajqōnēn Dāwid 'et-haqqînâ hazzôt”, co można przetłumaczyć również: „zaczął zawodzić Dawid taką [tę oto, następującą] pieśń żałobną". Charakterystyczną cechą semantyki hebrajskiej jest częste łączenie ze sobą dwóch czasowników lub czasownika i rzeczownika mających ten sam rdzeń, w celu zwiększenia ciężaru wyrażanej myśli lub zapewnienia skuteczności zapowiadanego w tekście działania $^{11}$. Czasownik uważany jest za oficjalnie, nawet ceremonialnie wprowadzający w śpiew żałobny, jakkolwiek tematyka utworu może być całkowicie różnorodna ${ }^{\mathrm{I} 2}$. Pochodzenie rzeczownika qînâ, jak wskazuje treść obecnie prezentowanej pieśni, należy uważać za początkowo całkowicie świeckie ${ }^{\mathrm{I} 3}$. Potwierdza to także prezentowany utwór, w którym wcale nie ma mowy o Bogu. Prawdopodobnie jednak korzenie gatunku wyrastają ze zwyczaju indywidualnego lub rodzinnego opłakiwania śmierci najbliższych $^{\mathrm{I} 4}$. W przedstawianej pieśni rola opłakujących przypada samemu następcy tronu oraz całej jego świcie. Celem nadrzędnym jest tu poetyckie wyrażenie bólu spowodowanego śmiercią stosunkowo bliskich sercu osób (2 Sm 1,24; 3,33; Jr 9,17). Z reguły qînâ jako pieśń żałobna śpiewana była przy zmarłym, położonym już na marach w domu rodzinnym, lub przy jego grobie, jak to się czyni w naszych czasach ${ }^{\mathrm{I}}$. Poświadcza to zwłaszcza staro-

II Por. m.in.: Rdz 3,4; 20,7; 50,15; Lb 13,30; Pwt 4,26; 8, 19; 30,18; 31,29; $1 \mathrm{Sm} 20,3 ; 24,21 ; 26,25 ; 30,8 ; 2 \mathrm{Sm} 12,14 ; 17,9 ; 1 \mathrm{Krl} 2,37$.

I2 Por. również: $2 \mathrm{Sm} 3,33 ; 2 \mathrm{Krn} 35,25 ; \mathrm{Jr}$ 9,16; Ez 27,32; 32,16.

${ }_{3}$ Zob. C. Westermann, Forschung am Alten Testament. Gesammelte Studien II, red. R. Albertz, E. Ruprecht, München 1974, s. 251-252.

${ }_{14}$ Zob. H.P. Müller, Gilgameschs Trauergesang um Enkidu und die Gattung der Totenklage, „Zeitschrift für Assyriologie und Vorderasiatische Archäologie Berlin” 1978, t. 68, nr 2, s. 237. Niektórzy badacze widzą tu typ pieśni śpiewanej raczej przez obcych niż najbliższych - zob. H.J. Kraus, hôj als profetische Leichenklage über das eigene Volk im 8. Jabrbundert, „Zeitschrift für die Alttestamentliche Wissenschaft" 1973, t. 85, s. 19-23.

I5 Zob. E.F. de Ward, Mourning Customs in 1,2 Samuel, „The Journal of Jewish Studies" 1972, t. 23, nr 1, s. 1-27; nr 2, s. 145-166. 
żytny tekst opowiadający o płaczu Dawida nad grobem Abnera, zamordowanego dowódcy wojsk Saula (2 Sm 3,33).

Najczęściej śpiew qînâ charakteryzuje się przeplataniem metrum bikolonu i trikolonu, co pozwala identyfikować śpiew o opisywanym tu charakterze. Odnaleźć go można zwłaszcza w tekście lamentacji (Lm 1-5) oraz Księgi Izajasza (Iz 14,4-21), zaś schemat metryczny sylab akcentowanych do nieakcentowanych 3:2 - choć nie w każdym przypadku - dominuje zarówno w Drugiej Księdze Samuela (2 Sm 1,19-27), jak i w strukturze Księgi Lamentacji ${ }^{16}$.

\section{Kompozycja elegii}

Po tym wstępnym omówieniu możemy przystąpić do przedstawienia kompozycji wersetów 19-27, stanowiących właściwą treść elegii, jaką Dawid odśpiewał nad zabitym w walce królem. Sam utwór znajduje się w szerszym kontekście (2 Sm 1,1-2,7), wyraźnie podzielonym na trzy główne części:

A. Zawiadomienie Dawida o śmierci Saula $(1,1-16)$

1. Przyjęcie nowiny $(1,2-10)$

2. Reakcja na nowinę $(1,11-16)$

B. Lamentacja nad Saulem i Jonatanem (1,17-27)

1. Stwierdzenie żalu, śpiewu i adnotacji w „Księdze Sprawiedliwego" (1,17-18)

2. Fundament żalu Dawida $(1,19)$

3. Przeciw nieprzyjaciołom i polu bitwy $(1,20-22)$

4. Pochwała pobitych $(1,23-27)$

C. Ustanowienie i umocnienie panowania Dawida jako króla Judy $(2,1-7)$

1. Przeniesienie się z wygnania do Hebronu $(2,1-3)$

2. Namaszczenie na króla nad Judą $(2,4 a)$

3. Zawiadomienie o uczynku mieszkańców miasta Jabesz chowających Saula $(2,4 b-7)$.

Taki układ materiału pozwala autorowi biblijnemu przejść płynnie od jednego panowania do drugiego z mocnym usprawiedliwieniem faktu, że panowanie w Izraelu przejmuje ktoś, kto nie należał do dynastii królewskiej. Hagiografowie co prawda uczynili wiele, by legitymizować Dawida na urzędzie królewskim, zwłaszcza przez jego bohaterskie czyny (1 Sm 17,32-58), ożenek z Mikal, córką Saula (1 Sm 18,20-22), akceptację jako

${ }^{16}$ Zob. W.H. Shea, The qinab Structure of the Book of Lamentations, „Biblica Romana” 1979, t. 60, nr 1, s. 103-107. 
wodza przez żołnierzy armii królewskiej, wreszcie relacjonując prześladowania niewinnego Dawida przez zazdrosnego króla (1 Sm 18,5-30; 19,8-20). Na te wydarzenia historyczne nakłada się cała teologia odrzucenia Saula, jako króla, przez Boga i wybór młodego Dawida na jego następcę, jeszcze za życia pierwszego władcy (1 Sm 16,1-13). Odrzucenie to fundowane jest na podwójnej winie króla wobec Boga: złożeniu nieprawej ofiary (1 Sm 13,9-14) oraz chciwości na dobra pokonanych Amalekitów (1 Sm 15,13-29). Te dwa teksty wręcz dyskredytują panowanie pierwszego monarchy i założyciela państwa ${ }^{\mathrm{I}}$. Z drugiej strony, następca tronu prezentowany jest jako człowiek odważny, uczciwy, o nieskazitelnym charakterze, potrafiący wybaczać i niechowający urazy ${ }^{\mathrm{I}}$. Takie nagromadzenie materiału historyczno-teologicznego ma swe uzasadnienie w szczególnie napiętej kwestii samego przejęcia tronu przez Dawida, co dokonało się de facto etapami, z których pierwszy ukazany jest właśnie we fragmencie 2,1-7: Dawid nie zostaje natychmiast władcą całego Izraela, lecz pierwotnie tylko w Judzie, na terytorium, z którego pochodził i którego cząstkę stanowił. Raz jeszcze warto tu wspomnieć jego decyzję ukarania śmiercią tego, który przyniósł mu oznaki władzy królewskiej. Dawid nie jest zatem ukazany jako czyhający na koronę i pragnący zagarnąć królestwo dla siebie, lecz jako ten, przed którym sam Bóg usuwa kolejne przeszkody na drodze do władzy. Zostaje w ten sposób zwolniony z wszelkiej odpowiedzialności za wynikłą po klęsce Saula sytuację. W takim kontekście wspomniana elegia pełni funkcję raczej apologii samego śpiewającego ją Dawida niż pieśni na cześć zmarłego króla. Wyraża tyleż głęboki, co rzeczywisty stan emocjonalny człowieka zdolnego do współczucia i patriotyzmu ${ }^{19}$. Znienawidzony przez poprzednika, prześladowany, wygnany, ścigany, potrafi przejść nad tym do porządku dziennego i - świadomy roli, jaką odgrywał pierwszy monarcha państwa izraelskiego - ubolewa nad nim głęboko, śpiewając żałobny tren po jego śmierci. W ten sposób zaznacza, jak wielką

${ }_{77}$ Jakkolwiek w niektórych kręgach pisarskich zachowały się pochwały

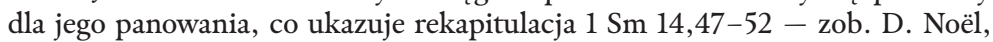
Naissance de la royauté en Israël et Juda, „Cahiers Evangile” 1993, nr 83: Bible et Royauté, s. 22.

I8 Niektóre historyczne perykopy świadczą o wyraźnie ambiwalentnym zachowaniu historycznego obrazu Dawida, którego postępowanie okazuje się nie tak nieskazitelne, jak chciałby to pokazać autor biblijny - zob. P. Gibert, Les Livres de Samuel et des Rois: de la légende à l'bistoire, „Cahiers Evangile” 1977, nr 22, s. 21-24.

I9 Zob. H.W. Hertzberg, I\& II Samuel, London 1964, s. 237. 
czcią go darzył, i podkreśla, że nigdy nie podważał prawa Saula i jego rodziny do tronu izraelskiego ${ }^{20}$.

Szczegółowy rozkład materiału pieśni po wprowadzających wersetach 17-18 wygląda następująco:

A. Fundament żalu Dawida (w. 19)

1. Treść lamentacji (w. 19a)

2. Refren (w. 19b)

B. Przeciw nieprzyjaciołom i polu bitwy (w. 20-22)

1. Przeciw radości nieprzyjaciół (w. 20)

2. Przeciw żyzności pola walki (w. 21-22)

C. Pochwała poległych w boju (w. 23-27)

1. Wspólna pochwała Saula i Jonatana (w. 23)

2. Eulogia na cześć Saula (w. 24-25a)

a. Wezwanie do lamentowania (w. 24a)

b. Właściwa pochwała (w. 24b)

c. Rozszerzony refren (w. 25a)

3. Eulogia na cześć Jonatana (w. 25b-27)

a. Wyrażenie lamentacji (w. 25b)

b. Właściwa pochwała (w. 26)

c. Rozszerzony refren (w. 27) ${ }^{21}$.

Na uwagę zasługuje tu zwłaszcza część trzecia, ułożona bardzo przejrzyście i paralelnie w budowie członów C. $2-3$. Całość jednak zostaje spięta refrenem w wersetach 19b.25a.27. Można $\mathrm{z}$ tego wnosić, że dzisiejsza biblijna postać utworu nie jest historycznym dziełem samego Dawida, lecz późniejszym, redaktorskim opracowaniem. Wskazuje na to również wołanie o pustynność wzgórz w wersetach 21-22, co wynika najprawdopodobniej $\mathrm{z}$ współczesnego wyglądu tego obszaru: terenu naturalnie niezalesionego, wysuszonego i opustoszałego pośród żyznej ziemi' ${ }^{22}$.

${ }^{\circ \circ}$ Zob. J.H. Grønbaek, Die Geschichte vom Ausstieg Davids (1. Sam. 15-2. Sam. 5): Tradition und Komposition, Kopenhagen 1971, s. 219-220.

${ }^{2 I}$ Podział na podstawie A.F. Campbell, 2 Samuel, Grand Rapids-Cambridge 2005, s. 22.

${ }_{22}$ Nawet współcześnie zwiedzający te wzgórza zapaleńcy piszą: „,Today indeed despite the efforts of modern Israeli farming and forestation by the Jewish National Fund, huge bald gaps confirm David's curse" (np. http://erikretallick.amplify.com/2010/07/19/mount-gilboa-once-cursed-now-blooming/ [dostęp: 15 marca 2011]). Należy zauważyć jednak liczne i skuteczne próby zmiany w zakresie zalesienia i regulacji florystycznej wzgórz podejmowane przez Jewish National Fund (http://www.jewishvirtuallibrary.org/jsource/ Society_\&_Culture/geo/Gilboa\%20.html [dostęp: 15 marca 2011]). 


\section{Treść utworu}

Nowoczesny przekład w ostatnich latach zaproponował Juliusz Stanisław Synowiec i dla potrzeb niniejszego opracowania nim się właśnie posłużymy ${ }^{23}$, jakkolwiek z kilkoma istotnymi poprawkami, co zostanie zaznaczone każdorazowo w brzmieniu tekstu:

$1{ }^{19}$ Ach!24 Chluba [twa], Izraelu, na twych wzgórzach zabita! Czemuż polegli bohaterowie?

${ }^{20}$ Nie mówcie o tym w Gat, nie rozgłaszajcie na ulicach Aszkelonu, by się nie cieszyły córki nieobrzezanych.

${ }^{21}$ Góry Gilboa, ani rosa, ani deszcz niech na was nie pada! I niechaj z was znikną urodzajne pola!

Bo tam tarcza bohaterów została skalana! Tarcza Saula nie oliwą była namaszczona, 22 ale krwią zabitych, thuszczem bohaterów. Łuk Jonatana nie cofał się nigdy, miecz Saula nie wracał bez skutku.

${ }^{23}$ Saul i Jonatan, mili i uroczy, w życiu i w śmierci byli nierozdzielni. Zwinniejsi niż orly, niż lwy mocniejsi.

${ }^{24}$ Płaczcie nad Saulem, córki Izraela! Ubierał was w purpurę $\mathrm{i}$ wystawne szaty, wasze suknie obwieszał ozdobami ze złota.

${ }^{25}$ Czemuż polegli bohaterowie $\mathrm{w}$ ciągu tej walki? Na twych wzgórzach Jonatan zabity!

${ }^{26}$ Ból mnie nad tobą ściska, bracie mój, Jonatanie! Tak bardzo byłem pod twoim urokiem! Cudem dla mnie była twa przyjaźń, większym niżeli miłość ze strony kobiet.

${ }^{27}$ Czemuż polegli bohaterowie i przepadły wojenne narzędzia?

Werset 19 ukazuje wprost przyczynę żalu Dawida, którą stanowiła wiadomość o śmierci zarówno króla, jak i jego syna.

23 Zob. J.S. Synowiec, Izrael opowiada swoje dzieje, Kraków 1998, s. 131.

${ }^{24}$ Idąc za egzegezą P. Kyle McCartera Jr., zwrot haşşbîi iśrā'ēl należy prawdopodobnie odczytać jako $b \bar{o} \xi ̧ b \hat{\imath}$, „Oh! Gazela [twa], Izraelu”, co potwierdza składnia Am 5,16 - zob. P. Kyle McCarter Jr., II Samuel. A New Translation with Introduction and Commentary, New York 1984, s. 74. 
Treść lamentacji w wersecie 19a wyraża się stwierdzeniem istoty katastrofalnego dla młodej monarchii wydarzenia: oto padła największa chluba Izraela, jaką był jej władca. Tragedia zdaje się tym większa, że śmierć nastąpiła we własnym kraju, nie na obcej ziemi, na którą król udałby się z armią, by podbijać kolejne terytoria i powiększać obszar własnego królestwa. Powyższe tłumaczenie, skierowane bezpośrednio do Izraela, wydaje się najbardziej właściwe z racji zwrotu „na twych wzgórzach”, co wskazuje, że Dawid zwraca się właśnie do Izraela pojmowanego tu na dwóch płaszczyznach: ludzkiej i terytorialnej. Saul i jego armia byli rzeczywiście chlubą zarówno całego narodu, jak i terenów przez niego zamieszkałych. Autor w tym zwrocie rekapituluje całość zwycięskich poczynań wojsk izraelskich pod wodzą króla, do tej pory niezwyciężonego w swych dokonaniach. Rzeczownik şb̂̂ oznacza zarazem „gazelę" i „piękność, ornament”. Wydaje się, że drugie ze znaczeń byłoby tu odpowiedniejsze ${ }^{25}$, lecz jest to prawdopodobnie jedynie pozór, ponieważ w literaturze semickiego obszaru północno-zachodniego - w myśl szczegółowych badań porównawczych - gazelami nazywano bohaterów ${ }^{26}$. W samym wersecie właściwą paralelą jest zamieszczony na jego końcu przymiotnik gibbôrîm - „potężni, silni, mocarni”. Jeżeliby więc termin şeb̂̀ odnieść do wspaniałości wojowników, to połączenie başş'bî iśra' $\bar{e} l$, będące jedynym tego rodzaju w całej Biblii Hebrajskiej, wskazuje wprost na niezrównaną wartość i umiejętności tych, którzy dla całego Izraela stanowili dumę i dawali poczucie jego siły i niezwyciężoności. Jeszcze w dzisiejszym języku wielu narodów dodanie nazwy państwa do charakterystyki jakiegoś wybitnego jego obywatela czyni zeń kogoś wyjątkowego i niezrównanego, czego wymownym przykładem może być określenie Jerzego Michała Wołodyjowskiego „pierwszą szablą Rzeczypospolitej” w powieści Henryka Sienkiewicza. W Biblii znakomity przykład takiego rozumienia daje również werset z Księgi Judyty (Jdt 15,9), w którym starszyzna Jerozolimy i całego Izraela wychwala Judytę, mieszkankę Betulii. Otóż bohaterskim, graniczącym $\mathrm{z}$ desperacją działaniem $\mathrm{w}$ obozie asyryjskim uratowała ona miasto i kraj od pewnej utraty niepod-

25 Taki sens przyjmuje on m.in. w: Iz 28,1.5; Jr 3,19; Ez 7,20; 20,6.15; 25,9; Dn 11,41. Większość tekstów mówi tu jednak o pięknie ziemi, co od razu narzuca takie właśnie rozumienie omawianego rzeczownika.

${ }_{26}$ Zob. M. Dahood, The Value of Ugaritic for textual Criticism, „Biblica” 1959, nr 40, s. 161-162; P.D. Miller, Animal Names as Designation in Ugaritic and Hebrew, „Ugarit Forschungen” 1970, nr 2, s. 185. Taki sens rzeczownika potwierdzony został w 2 Sm 2,18; 1 Krn 12,9; Pnp 2,9.17; 8,14, jakkolwiek $\mathrm{w}$ trzech ostatnich tekstach brakuje kontekstu militarnego. 
ległości i kolejnej deportacji: „Tyś wywyższeniem Jeruzalem, tyś chlubą wielką Izraela, tyś wielką dumą naszego narodu" ${ }^{27}$.

Zawarty w dalszej części wypowiedzi Dawida zwrot 'albāmôtêk $\bar{a}$ - „na twych wzgórzach” - wyraża najgłębszy żal wynikający z patriotyzmu i miłości ziemi ojczystej ${ }^{28}$. We własnym kraju giną bowiem bohaterowie obrony jego niepodległości. Otwiera to drogę do zajęcia kraju przez nieprzyjaciół, co zresztą - jak wiadomo z Pierwszej Księgi Samuela (1 Sm 31,7b) - nastapiło niedługo po przegranej bitwie. Z punktu widzenia autora biblijnego jest to tym bardziej niebezpieczne, że jako poganie przynieśli oni ze sobą bałwochwalcze wierzenia, tak bardzo zagrażające kształtującej się dopiero wierze jahwistycznej w narodzie wybranym. W teologii biblijnej cały kraj jest własnością Boga i jako taki ma w całości należeć do narodu wybranego. Prawdopodobnie dlatego właśnie kilka wieków później prorok Ezechiel (Ez 36,2-12) zapowiada powrót wszystkich wzgórz (bāmôt $)$ izraelskich do prawowitego właściciela, jakim jest naród wybrany $^{29}$. Tekst ów znajduje w klęsce na wzgórzach Gilboa swe znakomite odniesienie historyczne i chociaż wygłoszony został długo po bitwie, właśnie werset 2 mógłby zostać włożony w usta zwycięskich Filistynów zajmujących kraj Izraela. Natomiast pozostałe wersety stanowią reakcję na pełne pychy słowa pogan, zwiastują Bożą interwencję przeciw nim w obronie Jego naro$\mathrm{du}^{30}$. W takim kontekście wyrocznia Ezechiela może być teologiczną odpowiedzią Boga na płacz Dawida, bezradnego wobec przewagi wroga nad wojskami izraelskimi ${ }^{3}$. Teologia sięga więc znacznie dalej, poza konkretne wydarzenie historyczne: mimo

27 Zob. S. Baksik, Ksiega Judyty. Wstęp - przektad z oryginatu - komentarz, w: Pismo Święte Starego Testamentu, t. 6, 1-3, Poznań 1963, s. 149-150. Kilka tekstów takie tytuły odnosi wprost do Boga, np. „nadzieja Izraela” w Jr 14,8 i 17,13 lub „Pasterz Izraela” w Ps 80,2.

${ }_{28}$ Wzgórza te pojmowane są w sensie geograficznym, jako miejsca tworzące dany krajobraz, podobnie w: Am 4,13; Mi 1,3; 3,12; Iz 58,14; Ps 18,34. Zob. także D.I. Block, The Book of Ezekiel. Chapters 25-48, Grand Rapids-Cambridge 1998, s. 327-328.

${ }_{29}$ Por. m.in.: Rdz 12,7; 13,17; 17,8; 26,3; 28,13; 1 Krn 16,18; Ps 135,12; 136,21 .

$3^{\circ}$ Działanie to skoncentruje się na odnowieniu wzgórz Izraela przez przywrócenie żyzności ich ziemiom, zasiedlenie ludnością oraz owocowanie drzew i roślin. Wszystko to jest przeznaczone dla narodu wybranego. Narody pogańskie zostaną ostatecznie wyrzucone (w. 6-7) - zob. M. Greenberg, Ezekiel 21-37. A New Translation with Introduction and Commentary, New York-London-Toronto-Sydney-Auckland 1997, s. 724.

${ }^{\text {I }}$ Podobną bezradność znów wieki później zamanifestuje autor Ps 79,1-8, wspominając bezsilność wobec tych, którzy wtargnęli do świątyni, splądrowali ją i zniszczyli. 
chwilowej klęski to, co raz zostało nadane narodowi wybrane$\mathrm{mu}$, zawsze ostatecznie do niego powróci.

Dopowiedzeniem przyczyn lamentacji Dawida jest stwierdzenie tragicznej śmierci bohaterów. Rzeczownik chālal „śmierć" ${ }_{22}$ - odnosi się w tym wersecie do dość suchej i oszczędnej w swej wymowie relacji autora $(1 \mathrm{Sm} 31,1.8)^{33}$. Jednak głębsza egzegeza tego konkretnego tekstu uwzględniająca pozabiblijne perykopy porównawcze prowadzi do wniosku, że chodzi o śmierć godną pochwały, uznania za odwagę w bitwie, mimo świadomości przegranej. Rzeczownik ów zawiera ideę stania twarzą w twarz wobec silniejszego wroga i trwania na placu boju do końca w pozycji stojącej, nieunikającej ciosów, lecz przyjmującej je ze świadomością konieczności obrony, w tym konkretnym wypadku obrony własnej ziemi i prawa do życia ${ }^{34}$.

Refren w wersecie 19b stawia z kolei pytanie retoryczne: Jak mogło dojść do takiej tragedii? Trudno ustalić definitywnie, co miał na myśli Dawid, wypowiadając owe słowa. Z jednej strony jest to zadziwienie tym, że potężna i niezwyciężona armia oraz waleczni w boju wodzowie ulegli armii nieobrzezanych, których dotąd bez większych trudów pokonywano (1 Sm 13-14). Z drugiej jednak - rodzi się pytanie o Bożą opiekę nad całym narodem, który bez króla może łatwo trafić do innej niewoli. Autor przedstawia Dawida jako nieświadomego Boskich wyroków odrzucających Saula jako króla, będących karą za wcześniejsze dwa występki nieposłuszeństwa, co oznacza cofnięcie od niego Bożej opatrzności. Paradoksalnie w planach Jahwe ta klęska utorowała Dawidowi drogę do tronu Izraela.

W wersecie 20 Dawid woła o nierozprzestrzenianie tej wieści wśród pogan, którzy radowaliby się z największego obecnie nieszczęścia Izraela. Tekst może zostać potraktowany jedynie jako pobożne życzenie, ponieważ taka wiadomość już się rozeszła pośród nieobrzezanych, wywołując powszechny aplauz $(1 \mathrm{Sm}$ 31,9-10). Jeśli historyczny Dawid rzeczywiście ową prośbę wygłosił, to z pewnością nie w tym celu, by ziściło się jego życzenie, lecz by poganie nie cieszyli się z klęski wojsk narodu wybranego. Pojawiające się w wypowiedzi dwa miasta, Gat i Aszkelon, to główne ośrodki życia społeczno-religijnego ówczesnej Filistei. Życie pierwszego z tych miast Dawid poznał dobrze, znalazł-

${ }^{32}$ W kontekście wojennym - por. m.in.: Joz 11,6; 13,22; Sdz 9,40; 16,24; 20,31.39; $1 \mathrm{Sm} \mathrm{17,52;} 2 \mathrm{Sm}$ 23,8.18; $1 \mathrm{Krl} 11,15 ; 1 \mathrm{Krn} 5,22$.

33 Wersety te zostają przywołane przez konstrukcję obu wyrazów chālal oraz nāpal, „paść”, obecnych także w omawianym tekście. Por. także np.: 1 Krn 5,22; 10,1.8; 2 Krn 13,17; Jr 51,4.47.49; Ez 6,7.

34 Zob. szerszą analizę P. Kyle McCartera Jr., op.cit., s. 74-75. 
szy tam schronienie przed Saulem, który go prześladował $(1 \mathrm{Sm}$ 27,2-4). Z kolei w Aszkelonie swego czasu Samson wprowadził terror, zabił co najmniej trzystu mieszkańców i złupił miasto (Sdz 14,19). Miasto to było więc bardzo zainteresowane radosnymi wiadomościami o pokonaniu wojsk izraelskich 35 . Dawid jednak nie wspomina o radości ogólnej, lecz jedynie o weselu kobiet filistyńskich (benôt pelištîm). Można zrozumieć to uściślenie, przeczuwając, że śmiech słabych kobiet pogańskich ze śmierci bohaterskich mężów izraelskich $\mathrm{w}$ walce będzie dla nich dodatkową ujmą. Wymowny jest tutaj cytat opowiadający o złośliwej i wzgardliwej radości Aramejek (benôt ărām) i Filistynek (benôt pelištîm) z poniżenia Izraela, ukaranego w ten sposób za bałwochwalstwo. Oto te, które same powinny zostać ukarane za idolatrię, śmieją się z tych, którzy poznając prawdziwego Boga, odrzucili Go i przeszli na stronę fałszu (Ez 16,57). Paradoks tkwi w fakcie, że Aramejki i Filistynki pozostały wierne swym przesądom, podczas gdy Izraelici odeszli od wierności jedynej prawdzie. Stąd zgryźliwe szyderstwo i kpina z losu członków narodu wybranego ${ }^{36}$. Podobną sytuację można zauważyć w życzeniu wyrażonym w elegii.

Werset 21 przynosi swoiste przekleństwo miejsca, które stało się świadkiem wielkiej klęski. Dawid, podając to miejsce, odnosi się do samego faktu historycznego, który przedstawiają Pierwsza Księga Samuela (1 Sm 31,1.8) oraz Druga Księga Kronik (2 Krn 10,1.8), a także do relacji żołnierza amalekickiego, który przyniósł mu tę nowinę (2 Sm 1,6). Druga Księga Samuela (2 Sm 21,12-14) ukazuje Dawida, który zachował na zawsze w pamięci samą walkę, jak i miejsce izraelskiego nieszczęścia, gdy - już jako król Izraela - po latach przybył do mieszkańców Jabesz w Gileadzie, by odebrać od nich kości Saula i Jonatana ${ }^{37}$. Klątwa rzucona na to miejsce przez Dawida ujawnia swój złowieszczy pierwiastek w świetle Pierwszej Księgi Królewskiej (1 Krl 17,1), zawierającej taki sam rozkaz, jaki wyszedł z ust proroka Eliasza w czasach panowania króla Achaba w Izraelu: żeby na ziemię królestwa nie padał deszcz (māțār) ani nie zraszała jej

35 Tekst prezentuje go jako obdarzonego nadludzką siłą przez samego Jahwe - zob. D.I. Block, Judges, Ruth. An Exegetical and Theological Exposition of Holy Scripture, Nashville 1999, s. 436.

${ }^{6}$ Widzącego siebie $\mathrm{w}$ dodatku zawsze jako lepszego, sprawiedliwszego $\mathrm{z}$ racji znajomości Jahwe, swego Boga - zob. D.I. Block, The Book of Ezekiel. Chapters 1-24, Grand Rapids-Cambridge 1997, s. 514-515.

37 Zapis ów służy zwłaszcza podkreśleniu osobowości Dawida, wiernego bezwzględnie i do końca swemu teściowi i przyjacielowi - zob. R.D. Bergen, 1,2 Samuel. An Exegetical and Theological Exposition of Holy Scripture, Nashville 1996, s. 447. 
rosa $(t a l)$ przez trzy i pół roku $3^{8}$. Oznaczało to całkowitą suszę, brak żywności, głód mieszkańców kraju - co w tamtych czasach było odbierane jako rzeczywiste przekleństwo danego miejsca rzucone przez Boga ${ }^{39}$. Powodem takiego biegu zdarzeń jest skalanie tarczy mocarzy, czyli ich upadek na ziemię. Jest to jednoznaczne $\mathrm{z}$ niemożnością podjęcia właściwej obrony przed ciosami przeciwnika. Tarcze, ponieważ były wykonane z grubej, garbowanej skóry, musiały być oliwione przed bitwą, co chroniło skórę przed wysuszeniem i popękaniem $\mathrm{w}$ palących promieniach słońca, nadawało jej elastyczność. Zwiększała się w ten sposób wydatnie skuteczność obronna samej tarczy i znacznie dłużej można było wykorzystywać ją w walce. Upadek na ziemię powodował jej zabrudzenie i osłabiał możliwość obrony $4^{\circ}$.

Poetyka wesetu 22a wskazuje, że wcześniejsze słowa Dawi$\mathrm{da}$ (w. 21b) o nienaoliwieniu tarczy Saula należy rozumieć przenośnie. Sens tekstu wyjaśnia się w stwierdzeniu, że na skutek zażartej batalii nie oliwa stanowiła właściwą pokrywę tarczy królewskiej, lecz krew i pot tych, którzy polegli, trzymając je w rękach. Ponadto hebrajskie chēleb, „tłuszcz”, często oznacza „wartość, dobrobyt, zamożność lub zdrowie” ${ }^{4}$. Tekst Księgi Sędziów $(\mathrm{Sdz} 3,22)$ dostarcza tu dobrej paraleli, informując wpierw o otyłości moabskiego króla Eglona (w. 17), świadczącej o dobrobycie, zamożności i dostatku. Cios zadany władcy nożem przez Ehuda z Izraela utknął w tłuszczu królewskiego brzucha, dlatego ów rzeczownik w kontekście walki odsyła także do idei siły, mocy i waleczności ${ }^{2}$. Z tego powodu spływający po tarczy thuszcz obrońców należy interpretować jako upadek ich walecznej siły i porażkę $\mathrm{w}$ starciu $\mathrm{z}$ filistyńskimi przeciwnikami.

$\mathrm{Z}$ kolei werset $22 \mathrm{~b}$ akcentuje niezrównaną odwagę i męstwo w bojach zarówno króla, jak i jego syna. Każdej z postaci pie-

$3^{8}$ Zob. M.A. Sweeney, I \& II Kings. A Commentary, Louisville-London 2007, s. 211.

39 Teksty Rdz 49,25 oraz Pwt 33,13 ukazują wody wypływające z gór oraz spadające z nieba jako błogosławieństwo dla ziemi i człowieka. Podobne imprekacje zawiera także literatura ugarycka i babilońska. W suchym klimacie zwrotnikowym wartość wody jest nie do przecenienia - zob. P. Reymond, L'eau, sa vie et sa signification dans l'ancient Testament, Leiden 1958, passim.

$4^{\circ} \mathrm{P}$. Kyle McCarter Jr. przeprowadza skrupulatną analizę poszczególnych terminów hebrajskich. Przywoływanie jej w niniejszym artykule nie jest potrzebne, jednak zainteresowanego czytelnika odsyłamy do wspomnianej książki autora (s. 76).

${ }^{4}$ Por. m.in.: Wj 3,8.17; Lb 13,27; 14,8; Pwt 32,13-14; Hi 14,27; Ps 17,10; 63,$6 ; 73,7 ; 81,17 ; 119,70 ; 147,14$; zwłaszcza w kontekście tłustości składanych ofiar: 1 Sm 15,22; 2 Krn 29,35; Iz 1,11; 43,24; Ez 44,15.

$4^{2}$ Zob. D.I. Block, Judges Ruth..., s. 166. Podobne odniesienia terminologiczne spotkać można także w Iz 34, 6-7. 
śniarz przypisuje właściwe narzędzie walki: łuk należy do Jonatana, podczas gdy miecz znajduje się w ręku Saula. Działanie obu wojowników zostało nakreślone dwoma czasownikami charakteryzującymi przede wszystkim dzielność walczących i idącą za nią skuteczność użycia narzędzi w boju: łuk Jonatana „nigdy się nie cofał”, zaś miecz Saula „nie powracał ku niemu daremnie”. Łuk używany przez syna królewskiego pojawił się już w Pierwszej Księdze Samuela, gdy jako wyraz przyjaźni z Dawidem zo-

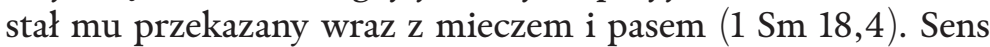
pierwszego działania zostaje najlepiej ukazany w porównaniu nikczemników do zawodnego łuku: ludzie odstępujący od Bożego prawa są jak zawodzący w walce łuk, który zamiast celnie razić strzałami, w najważniejszym momencie psuje się i nie wypełnia swego zadania (Ps 78,57). Naraża tym samym swego strzelca na bezpośrednią utratę życia ${ }^{43}$. Natomiast w myśl innego wersetu niecofanie się $\mathrm{w}$ boju jest najważniejszym znamieniem odwagi walczących (Jr 46,5)44. Można więc wypowiedź dotyczącą Jonatana zrozumieć jako przejaw ogromnej odwagi, wyrażającej się przez brawurę natarcia $\mathrm{z}$ łukiem, który nigdy nie zawodzi i razi celnie przeciwników, padających pod celnymi ciosami strzał. $\mathrm{Z}$ kolei miecz to charakterystyczne narzędzie walki samego króla 45 . Dawid przywołuje tu wiele wcześniejszych bitew, w których władca wykazał się walecznością w boju i zwycięstwami dla swego narodu, choćby pierwsze starcie z Filistynami $(1 \mathrm{Sm}$ 13,1-23) oraz Amalekitami (1 Sm 15,1-9), jakkolwiek autorzy biblijni z pewnością nie wymieniają wszystkich ${ }^{46}$. Wartościowe jest tu zakończenie Dawidowej eulogii akcentującej, że miecz

43 Zob. J. Goldingay, Psalms 2: Psalms 42-89, Grand Rapids 2007, s. 507-508 .

44 Zob. G.L. Keown, P.J. Scalise, T.G. Smithers, Jeremiab 26-52, Dallas 1995, s. 291.

45 Połączenie chereb oraz šẩ'ûl zawarte jest również w 1 Sm 13,22; 17,38; 31,4; 1 Krn 10,4.

${ }^{46}$ Trudno ustalić, czy tekst ten oddaje prawdę historyczną, ponieważ dość liczne passusy biblijne ukazują powracający paniczny strach Saula przed kolejnymi potyczkami, jak np. przed bitwą z Filistynami w 1 Sm 17,11 oraz 28,5.20. Ponadto nie można pominąc ką́liwej piosnki kobiet izraelskich, notowanej przez 1 Sm 18,6-7, które sławiły Dawida za dziesiątki tysięcy zabitych na polu walki, podczas gdy Saulowi przypisywały jedynie tysiące, co spowodowało nieuniknioną zazdrość króla wobec swego dowódcy. Teksty te należy jednak zapewne traktować jako fikcję literacką mającą służyć tworzącej się ideologii Dawida - właściwego króla Izraela. Stąd też stopniowe wywyższanie następcy króla przez autorów biblijnych kosztem jego samego. Najprawdopodobniej właśnie eulogia Dawida stanowi odzwierciedlenie prawdy historycznej mówiącej o domniemanej waleczności Saula. Ciekawe studium historyczne proponuje tu G.E. Wright, Fresh Evidence for the Philistine Story, „The Biblical Archaeologist” 1966, nr 29, s. 70-86. 
Saula nie powracał rêqām, „bezowocnie”, co w świetle prorockiej zapowiedzi (Jr 50,9), mówiącej o wyjątkowej skuteczności przyszłych wrogów Babilonu, pozwala tę samą cechę i rolę przypisać właśnie mieczowi królewskiemu w wojnie z wrogami Izraela ${ }^{47}$.

Treścią wersetu 23 jest równoczesne wspomnienie ojca i syna. Twórca elegii przedstawia ich tak, jak ich zapamiętał. Pierwsza część akcentuje wzajemne relacje bohaterów: kochających się (banne' $b \bar{a} b \hat{\imath} m)^{48}$, milych, uczynnych dla siebie (bann $\left.{ }^{e} \hat{\imath} \mathrm{imim}\right)^{49}$ i nierozdzielnych (lô niprādû) tak za życia, jak po śmierci ${ }^{\circ}$. Zebranie w jednej wypowiedzi tych cech, charakterystycznych dla relacji ojcowsko-synowskich, podsumowuje i zarazem pomija niektóre trudne sprawy z życia obu wodzów, czego powodem był właśnie Dawid, z którym Jonatan związał się silną przyjaźnią. Autor biblijny notuje zarzut, jaki Saul postawił Jonatanowi: chodziło o spiskowanie przeciw niemu (1 Sm 22,13). Podstęp ów miał polegać na nieustannej ochronie, jaką syn króla zapewniał zbiegowi, powiadamiając go o wszystkich postanowieniach i akcjach Saula wymierzonych przeciw Dawidowi (1 Sm 20,1-42). Szczegół ów nie przeszkadza jednak w dokonaniu zbiorczej oceny życia obu dowódców, ponieważ - rzeczywiście - poza różnicą zdań na temat Dawida między Saulem a Jonatanem istniała silna więź miłości ojca i syna oraz wynikające z niej posłuszeństwo. Ich wspólna śmierć na polu walki jest jakby ukoronowaniem jedności, jaką budowali przez całe swe życie.

Druga część tego tekstu przywołuje zwłaszcza wojenne działania obu, podkreślając ich umiejętność postrzegania spraw oraz odwagę. Przyrównanie tych akcji do bystrych oczu orłów ma przekonać, że żadna $\mathrm{z}$ nich nie była chybiona, wręcz przeciwnie - wszystkie były doskonale przemyślane, dla dobra młodej monarchii, skierowane były przeciw jej nieprzyjaciołom, co można zauważyć również $\mathrm{w}$ podobnie brzmiącym cytacie z Księgi Powtórzonego Prawa (Pwt 32,11) ${ }^{5 x}$. W świetle innych

47 Zob. J.A. Thompson, The Book of Jeremiah, Grand Rapids 1980, s. 734.

$4^{8}$ Nigdzie teksty biblijne nie notują czasownika 'āhēb w relacjach Saula

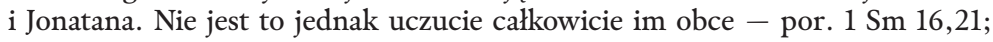
18,$1 ; 20,17$.

49 Tego przymiotnika we wzajemnych relacjach obu bohaterów nie notuje nigdzie tekst biblijny. Autor biblijny użył tu ogólnego wyrażenia na określenie bogactwa wzajemnych relacji między ojcem a synem: jeden drugiemu sprawiał radość swoim życiem i działalnością.

50 Ostatni z wymienionych zwrotów nie wymaga dowodu, ponieważ całość tekstów biblijnych przedstawiających Saula i Jonatana ukazuje ich zawsze razem, zwłaszcza w ważnych momentach życia kraju.

${ }^{{ }^{\mathrm{I}}}$ Jest to jeden $\mathrm{z}$ najważniejszych etapów przygotowujących potomstwo do dojrzałości i samodzielności (zob. E.H. Merrill, Deuteronomy. An Exegetical and Theological Exposition of Holy Scripture, Nashville 1994, s. 414). W tym 
wersetów (Pwt 28,49; Jr 4,13) wartościową cechą jest tu także szybkość przeprowadzonego ataku, niejednokrotnie zaskakująca przeciwnika - ta, której mistrzami są właśnie orły ${ }^{2}$. Skuteczność i ściganie aż do schwytania ofiary widać z kolei w zestawieniu z Księgą Hioba (Hi 9,26)53. Wreszcie całkowitą dla wrogów nieprzewidywalność działań podkreśla Dawid (na tle Prz 30,19)54. Na koniec wypada zauważyć, że takie akcje wojenne mogły się wydarzyć tylko dzięki szczególnej opiece Boga Izraela, który na podobieństwo siły orła odnawia siły władców swego ludu (Ps 103,555; Iz 40,3156). Przyrównanie Saula i Jonatana do lwów nie wymaga zaś szczególnego objaśnienia - akcentuje ono przede wszystkim ich dzielność w bitwach i wytrwałość na placu boju. Warto jedynie zwrócić uwagę na swoistą krwiożerczość tych zwierząt, co w zestawieniu z działaniami wojennymi oznacza nieustawanie w walce aż do całkowitego zniszczenia przeciwnika (Lb 23,2457). Decydujące znaczenie ma tu siła ataku $\left(\mathrm{Iz} 38,13^{8}\right)$. Z kolei w dwóch innych miejscach tekstu biblijnego $\left(\mathrm{Lb} 24,959 ; \mathrm{Lm} 3,10^{60}\right)$ uwaga skupia się przede wszystkim na momencie czajenia się i podchodach drapieżników w celu za-

kontekście należy być może widzieć działanie Saula i Jonatana jako wskazówkę do dalszego postępowania Izraelitów zachęcanych do bohaterstwa.

$5^{2}$ Mimo że kontekst Jr 4,13 jest tu różny, sama szybkość zaskoczenia przez przeciwnika ukazana została wręcz jako ostrzeżenie przed lenistwem duchowym i brakiem nawrócenia - zob. L.C. Allen, Jeremiah. A Commentary, Louisville-London 2008, s. 66.

53 Kolejne przykłady, obrazujące zwłaszcza szybkość ścigania, przedstawił G. Ravasi, Hiob. Dramat Boga i człowieka, część 2, przeł. K. Stopa, Kraków 2005, s. 138-139.

54 Zob. B.K. Waltke, The Book of Proverbs. Chapters 15-31, Grand Rapids-Cambridge 2005, s. 491.

55 Odnowienie to ma nie tylko ratować przed niechybną śmiercią, lecz ogólnie wzmacniać siły życiowe - zob. J. Goldingay, Psalms 3: Psalms 60-150, Grand Rapids 2008, s. 168.

${ }^{6}$ Dzięki temu ci, którzy w Bogu pokładają nadzieję, niczego nie muszą się obawiać, zwłaszcza rozbicia o ziemię, co zapewnia stałe wsparcie i siły od Boga - zob. J.N. Oswalt, The Book of Isaiah. Chapters 40-66, Grand Rapids 1998, s. 74-75.

57 Tekst ten ukazuje samego Izraela, obdarzonego przez Boga niemal nadludzkimi możliwościami zwyciężania przeciwników (zob. T.R. Ashley, The Book of Numbers, Grand Rapids-Cambridge 1993, s. 482). Znów zwraca to uwagę na Saula i Jonatana cieszących się taką siłą dzięki wierności Bogu.

${ }^{8} 8$ Bóg przyrównany do lwa miażdży wszystko, co wskazuje zarówno na niezniszczalną Jego siłę, jak i niemożliwość jakiejkolwiek obrony ofiary, zwłaszcza ciężko chorej - zob. G.V. Smith, Isaiah 1-39. An Exegetical and Theological Exposition of Holy Scripture, Nashville 2007, s. 647.

59 Zob. R.D. Cole, Numbers. An Exegetical and Theological Exposition of Holy Scripture, Nashville 2000, s. 422.

6o Sam Jahwe zostaje $\mathrm{w}$ ten sposób opisany jako nieprzyjaciel własnego ludu - zob. D. Garrett, P.R. House, op.cit., s. 411. 
skoczenia ofiary i odcięcia jej możliwości ucieczki. W ten sposób można by symbolicznie określić skuteczność planowania batalii, manewrów wojsk oraz właściwego rozmieszczenia sił - pozwalających osiągnąć zamierzone rezultaty. Całkiem podobnie wygląda postępowanie przywoływanych królów zwierząt. Opisana w Księdze Ezechiela (Ez 22,25) seria działań niegodziwych następców Dawida w czasach późniejszych, ukazuje wielkość spustoszenia, jakie czynili pośród mieszkańców $\mathrm{kraju}^{6 \mathrm{I}}$, co w oczach wrogów Izraela mogło być odniesione także do Saula i Jonatana. Wszystko to musiało ostatecznie wzbudzać niemały strach wrogów, podobnie jak wzbudza go powszechnie lew ( Prz 22,136 $\left.\operatorname{Jr} 51,38^{63}\right)$.

Najprawdopodobniej to podsumowanie dotyczy także ostatniej z bitew, która zamieniła się w klęskę. Sama porażka bowiem nie odbiera chwały bohaterstwa tym, którzy zginęli.

Logicznie dalszym ciągiem trenu Dawida będzie zatem wezwanie do opłakiwania ich śmierci przez kobiety izraelskie, co następuje $\mathrm{w}$ wersecie $24^{64}$. Uzasadniając wezwanie, autor nie odnosi się jednak ani do bohaterstwa obu wojowników, ani do ich troski o kraj, lecz czyni to znacznie bardziej przyziemnie. Przyczyną opłakiwania - tym razem samego króla - ma być wspomnienie zamożności, jaką cieszyli się Izraelici za czasów Saula. Na co dzień wyrażała się ona w pięknie stroju kobiecego i cenie materiałów tekstylnych, a także w drogocenności ozdób, zwłaszcza ze złota. Najprawdopodobniej kobiety, które zwłaszcza wówczas nie zajmowały się wielką polityką, prowadząc życie całkowicie zamknięte w obrębie ogniska domowego, nie rozumiały wielkiej polityki i znacznie bardziej nośnym argumentem dla wylewania żalu nad zmarłym jest brak tego, czego odtąd miały zostać pozbawione w swych codziennych sprawach. Można domniemywać, że zbytki te pochodziły najczęściej (najprawdopodobniej) z łupów wojennych, przywożonych do kraju po wygranych bataliach. Dlatego płacz kobiet nie powinien kończyć się na żalu za utraconymi dobrami, lecz wiązać się również z trwo-

${ }^{6 r}$ Jest to bardzo paradoksalne użycie wyrazu „lew”, który w odniesieniu do rodziny królewskiej był symbolem nobilitacji, powagi i potęgi. Obecnie symbol zmienił swój sens, stając się obrazem krwiożerczości, chciwości i wrogości wobec własnych poddanych - zob. D.I. Block, The Book of Ezekiel. Chapters $1-24 \ldots$, s. 725.

${ }^{62}$ Zob. B.K. Waltke, op.cit., s. 213.

${ }_{63}$ Porykiwanie świadczy o głodzie oraz wzrastającej gotowości do ataku. Ofiary nie ujdą przeznaczeniu - zob. G.L. Keown, P.J. Scalise, T.G. Smithers, op.cit., s. 371.

${ }^{64}$ Opłakiwanie takie, jakkolwiek z różnych okazji, było zwyczajem starożytnych społeczności, co ukazują m.in.: Pwt 34,8; 2 Sm 11,26; 14,2; Jr 31,15. 
gą o przyszłość. Skoro nie ma obrońcy, los mieszkańców Izraela jest wielce zagrożony, czego wyraźnym przykładem jest uwaga hagiografa o ucieczce mieszkańców bliższych Filistynom części Izraela przed zwycięzcami (1 Sm 31,7).

Jeżeli werset 24 ograniczył się do samego Saula, to werset 25a na moment znów zestawia obu bohaterów, by w swej drugiej części przejść do samego Jonatana. Werset rozpoczyna się od retorycznego pytania: 'êk, „jakże?”, w domyśle: „jak to mogło się w ogóle stać?". Pytanie to znajduje swe uzasadnienie w przekonaniu o niezwyciężonej waleczności obu wojowników, przejawiającej się zarówno w samym sposobie walki, jak i w dotychczasowych sukcesach militarnych. Zadziwienie wynika $\mathrm{z}$ faktu, że śmierć zabrała swe ofiary właśnie podczas walki, z której do tej pory zawsze wychodziły zwycięsko. Czytelnik może sam być zaskoczony reakcją Dawida, bo przecież walka to najbardziej uprzywilejowany sposób spotkania ze śmiercią. Niemniej dzielność i męstwo Saula oraz młodość, siła i odwaga Jonatana miały być dla nich dostateczną ochroną przed śmiertelnym zagrożeniem ze strony wrogich oddziałów. Warto w tym kontekście przypomnieć strategiczne umiejętności Jonatana oraz jego brawurę (1 Sm 14,1-16). O tym właśnie Dawid wiedział bardzo dobrze.

Dalej Dawid skupia się w swej elegii na samym Jonatanie, z którym wiązała go niezwykle silna przyjaźń, co autorzy biblijni zanotowali we wspomnianym już passusie (1 Sm 18,1-4; 20,1-42). Jeżeli jednak nie wspominali o odpowiedzi Dawida na zaoferowaną przyjaźń, obecnie składa on hołd właśnie Jonatanowi, który przyjaźń tę okazał nie tyle słowami czy jakimś uczuciem, ile czynem, chroniąc Dawida przed zemstą ojca. Oto w Pierwszej Księdze Samuela (1 Sm 20,4) mowa o gotowości Jonatana do spełnienia wszelkiej prośby Dawida, zaś werset 13 tej samej perykopy relacjonuje przysięgę wierności i lojalności, jaką Jonatan złożył przed Dawidem. Istotą tej przysięgi była gotowość przyjęcia wszelkich konsekwencji ewentualnej zdrady, łącznie $\mathrm{z}$ karą śmierci dla winowajcy. Jonatan był gotów raczej ją ponieść, niż pozwolić na skrzywdzenie Dawida przez Saula. W zamian zażądał jednak, by Dawid darzył go tą samą życzliwością za życia oraz później - by okazywał ją rodzinie Jonatana po jego śmierci, gdy sam obejmie już urząd królewski po Saulu (w. 14-15). Jest to całkiem zrozumiałe, zważywszy na fakt, że długo jedynie Dawid był beneficjentem przymierza, które dzięki zobowiązaniom Jonatana chroniło go przed zazdrością Saula. Z czasem, gdy po śmierci Jonatana cała dotychczasowa rodzina królewska miała przejść na łaskę nowego władcy, przysięga zobowiązała Dawida 
do ochrony rodziny zmarłego przyjaciela: by nikt nie ważył się podnieść na nią ręki - co też Dawid wykonał wobec Meribbaala, syna Jonatana, chroniąc go przed zamordowaniem $(2 \mathrm{Sm} \mathrm{21,7})^{65}$. Przyjaźń ta została przypieczętowana osobistym przymierzem obu mężów, któremu towarzyszyła obopólna przysięga wierności. Według wersetu 23 sam Bóg stał się gwarantem nierozerwalności przymierza.

W wersecie 26 Dawid nazywa swego druha 'āchî, „moim bratem”, oraz tym, który jest $n \bar{a}^{\prime} a m t \bar{a} m^{e} \bar{o} d$, „bardzo drogi, najmilszy”, zaś przyjaźń ceni bardziej od miłości kobiet. Braterstwo to, jak wynika z genealogii obu mężów, nie polega na pokrewieństwie, ponieważ wcale nie ma między nimi takiej zależności. Jest to jednak coś znacznie bliższego niż tylko wspólnota narodowa (Wj 4,18; Joz 17,4), wspólnota mieszkańców jednego miasta $(\mathrm{Sdz} 19,23)$ lub grono bliskich współpracowników $(1 \mathrm{Krn} 28,2)$. Chodzi o braterstwo zrodzone ze wspólnego systemu wartości, przekonań, celów i postępowania. Nie należy natomiast dopatrywać się w tym stwierdzeniu żadnych związków natury homoseksualnej, co sugerują niektóre środowiska gejowskie Europy Zachodniej i USA na podstawie fałszywej egzegezy tej wypowiedzi ${ }^{66}$. Jest to po prostu przyjaźń innej natury niż uczucie łączące mężczyznę i kobietę, przyjaźń stała, uczciwa i trwająca do końca życia obu partnerów. Obaj mężczyźni mieli przecież własne rodziny i dzieci, a perykopa w Drugiej Księdze Samuela (2 Sm 11,2-27), według której Dawid, pożądając kobiety, zdolny był do popełnienia najcięższej zbrodni, mówi sama za siebie. Z drugiej strony autor biblijny absolutnie nie deprecjonuje miłości mężczyzny i kobiety, chcąc jedynie zanotować wartość prawdziwej męskiej przyjaźni, zdolnej do oddania własnego życia za życie towarzysza.

Końcowy werset elegii znów stawia fundamentalne pytanie: 'êk, „jak? jakże?”, tutaj: „dlaczego? jak to było możliwe?” ${ }^{6}$. Pytanie to pełni funkcję podsumowania całej pieśni żałobnej. Nawiązuje do jej początku, wersetu 19b, gdzie zostało sformu-

65 Taką samą strukturę tekstu zauważyć można w Joz 2,12-13, gdy nierządnica Rachab, chroniąc szpiegów izraelskich, zaobowiązała ich, by po zdobyciu Jerycha zachowali przy życiu ją samą i jej rodzinę.

${ }^{66} \mathrm{Ku}$ błędnej interpretacji skłania szczególnie rozumienie czasownika $n \bar{a}$ 'ém (podobnie do Pnp 7,7), mówiącego jednak o miłości mężczyzny i kobiety, nie zaś dwóch mężczyzn. Takie stanowisko reprezentują m.in.: J. Boswell SameSex Unions in Premodern Europe, New York 1994, s. 135-137; D.M. Halperin, One Hundred Years of Homosexuality, New York 1990, s. 83.

${ }_{7}^{6}$ Przykłady pytań wyrażających zdziwienie w kontekście sytuacyjnym całkowicie innym od sugerowanego zawierają także m.in.: $2 \mathrm{Sm} \mathrm{1,14;6,9;} \mathrm{Ps}$ 11,$1 ; 137,4 ;$ Iz 14,12; 19,11; Jr 2,23; 47,7 . 
łowane po raz pierwszy. Drugie z pytań o tym samym charakterze dotyczy najprawdopodobniej zbroi i narzędzi walki, które przepadły w wyniku klęski. Co prawda użyty tu generalizujący termin milchāmâ oznacza w Biblii samą walkę, wojnę lub batalię, lecz kontekst wyraźnie sugeruje uzbrojenie wojenne. Już $\mathrm{w}$ wersecie $21 \mathrm{~b}$ pojawiło się ono jako tarcza, a w Pierwszej Księdze Samuela $(1 \mathrm{Sm} \mathrm{8,12)}$ odnaleźć można zwrot kelê milchamtô - „polowa broń wojenna”. Niektórzy egzegeci odnoszą ten rzeczownik do samych dzielnych wojowników, lecz układ treści utworu i składnia zdania hebrajskiego nie wskazują raczej takiego znaczenia ${ }^{68}$.

Prezentowana elegia to poetycki wyraz głębi uczuć człowieka, który cierpi po stracie najbliższych przyjaciół. Należy ona do największych osiągnięć wczesnej liryki hebrajskiej i chociaż nie zawiera wyraźnych odnośników religijnych, musi być rozumiana w kontekście teologii całego Starego Testamentu, z Bogiem w samym centrum życia wodzów Izraela i całego Jego ludu. Klęska w bitwie, nad którą lamentuje Dawid na kartach Biblii, przedstawiona jest nie jako przypadek lub zwykła kolej rzeczy, ale część planu Bożego, który paradoksalnie ułatwia przyszłemu królowi wstąienie na tron Izraela. Charakterystyczną cechą trenu jest wyłącznie pozytywne ukazanie głównych postaci. Takie przedstawienie ma być wyrazem czci. Pieśn tę należy traktować jako poetycki wyraz żalu nad umarłymi, nie zaś jako historyczny przegląd ich życia. Sposób ukazania życia bohaterów pozwala na wyciągnięcie wniosków ważnych dla słuchaczy $\mathrm{i}$ ich postępowania. Nie ma wątpliwości, że tak właśnie pojmował wygłaszany przez siebie utwór również Dawid: jego panowanie jest po części zasługą obu poległych w walce bohaterów ${ }^{69}$.

${ }_{68}$ Zob. D.N. Freedman, The Refrain in David's Lament over Saul and Jonathan, w: Ex Orbe Religionum: Studia Geo Widengren Oblata, red. C.J. Bleeker, Leiden 1972, s. 123.

${ }_{69}$ Zob. A.A. Anderson, 2 Samuel, Dallas 1998, s. 20. 


\section{JANUSZ NAWROT}

\section{"Lamentował Dawid żałobną pieśnią nad Saulem i Jonatanem, jego synem" - Davidic poetry reproduced in $2 \mathrm{Sm} \mathrm{1,17-27} \mathrm{as} \mathrm{a} \mathrm{Biblical} \mathrm{example} \mathrm{of} \mathrm{a} \mathrm{lamentation} \mathrm{poem}$}

The elegy in question presents and expresses in a poetic way the depth of feelings of a grieving man who suffers from the loss of his closest friends. The elegy belongs to the most illustrious achievements of early Hebrew lyric poetry and though it does not include distinct religious references in itself, it has to be understood within the context of the entire theology of the Old Testament that places God in the very centre of the life of the rulers of Israel and its people. The defeat in the battle so lamented in the Book by David himself is shown not as accidental or as a normal flow of things, but as part of God's plan that, ultimately and paradoxically, helps the future king of Israel conquer his enemies and ascend to the throne. A characteristic feature of the lamentation is an exclusively favourable presentation of the main protagonists so that due honour, reverence and glory can be rendered to them. Therefore, the only way to treat the song is to consider it as one that expresses grief and mourning over the deceased, and not as a historically reliable review of their life. The way the lives of heroes is presented makes it possible to draw conclusions for the audience that may be important and may shape individual lives and their future progress. Undoubtedly, this is how David viewed his song to be delivered to the audience, as well: his access to rule the country was partly the result of the sacrifice paid by the two heroes slain in the battle.

Key words: elegy, the Bible, Old Testament, the Books of Samuel, biblical theology.

\footnotetext{
KS. JANUSz NAWROT - profesor, wykłada na Wydziale Teologicznym UAM (także w sekcjach zamiejscowych w Gnieźnie i Obrze), związany również z UKSW (sekcja w Łodzi). Autor licznych artykułów publikowanych w pismach teologicznych oraz książek: Przyjażn w „Etykach” Arystotelesa, pismach madrościowych Septuaginty oraz w Nowym Testamencie (2004), „Badź dzielny i mocny, poniewaz Pan jest z toba”. Andreia i jej motyrwacja w Biblii greckiej (2006), „Prześladują biedaka i nieszczęśliwego”. Niegodziwcy wobec sprawiedliwych w psalmach suplikacji (2007), „Ushysz, o Panie, moją modlitwę, odpowiedz mi w swej sprawiedliwości!” (2009).

e-mail: jannaw@interia.pl
} 